\title{
Sexual behaviors of medical students: preliminary results
}

\author{
Fotini Ferenidou*, Aliki Patera, Nikolaos Vaidakis \\ From $1^{\text {st }}$ International Congress on Neurobiology and Clinical Psychopharmacology and European \\ Psychiatric Association Conference on Treatment Guidance \\ Thessaloniki, Greece. 19-22 November 2009
}

\section{Background}

Sexual problems are quite prevalent affecting up to $20-30 \%$ of men and up to $43 \%$ of women [1-4]. Information about sexual practices may help gain a better understanding of the occurrence of sexual problems and further improve their management.

\section{Materials and methods}

The study population included 231 medical students (99 men and 132 women) of the University of Athens, during the academic year 2008-2009. The participants were asked to complete a self - administered questionnaire which included demographic data and a questionnaire regarding sexual behaviors.

\section{Results}

Mean age of the participants was 24 years. More than half of them (67.1\%) reported having a sexual partner and $75.8 \%$ of them reported having sexual intercourse more than once a week. The decision preceded the act by a few seconds or minutes in $82.6 \%$ of subjects. Foreplay was important, very important or essential for $97.4 \%$ of subjects, while most of them (73.5\%) considered that foreplay was equally important for both partners. The majority of participants reported that they don't have a preferred timing $(67.1 \%)$ or season $(80.8 \%)$ for sexual intercourse. For most of the subjects it was very easy or quite easy to talk about sex with their sexual partner $(95.2 \%)$ or with their friends $(87.1 \%)$. The vast majority of the students reported informing themselves on sexual issues (83.8\%) and information sources were primarily acquaintances $(55 \%)$ and the internet (44.1\%).

\footnotetext{
First Department of Psychiatry, National and Kapodistrian University of Athens, /Eginition Hospital, Athens, Greece
}

\section{Conclusions}

Sexuality seems to be important for this group of young adults. The decision to have sex is spontaneous, foreplay is an important component of sexual intercourse and the time of the day or the year doesn't really matter. Students talk about sex quite open and inform themselves on sexual issues. This study employed a small, specific sample, thus the results are not representative of the general population.

Published: 22 April 2010

\section{References}

1. Lewis RW, Fugl-Meyer K, Bosch R, et al: Epidemiology/Risk Factors of Sexual Dysfunction. Journal of Sexual Medicine 2004, 1:35-39.

2. Laumann EO, Paik A, Rosen RC: Sexual dysfunction in the United States: prevalence and predictors. JAMA 1999, 281:537-44.

3. Feldman HA, Goldstein I, Hatzichristou DG, et al: Impotence and its medical and psychosocial correlates: results of the Massachusetts Male Aging Study. J Urol 1994, 151:54-61.

4. Dunn KM, Croft PR, Hackett Gl: Sexual problems: a study of the prevalence and need for health care in the general population. Fam Pract 1998, 15:519-24.

doi:10.1186/1744-859X-9-S1-S177

Cite this article as: Ferenidou et al:: Sexual behaviors of medical students: preliminary results. Annals of General Psychiatry 2010 9(Suppl 1): S177.

Submit your next manuscript to BioMed Central and take full advantage of:

- Convenient online submission

- Thorough peer review

- No space constraints or color figure charges

- Immediate publication on acceptance

- Inclusion in PubMed, CAS, Scopus and Google Scholar

- Research which is freely available for redistribution 